\title{
Headache Following COVID-19 Vaccination Among Healthcare Employees With a History of COVID-19 Infection: a Cross-sectional Study in Iran With a Meta-analytic Review of the Literature
}

\section{Somayeh Nasergivehchi}

Tehran University of Medical Sciences

Mansoureh Togha ( $\nabla$ togha1961@gmail.com )

Tehran University of Medical Sciences https://orcid.org/0000-0002-9368-6835

Elham Jafari

Tehran University of Medical Sciences

Mehrdad Sheikhvatan

Tehran University of Medical Sciences

Donya Shahamati

Shahid Beheshti University of Medical Sciences School of Public Health and Safety

\section{Research Article}

Keywords: Covid-19, Infection, Vaccination, Healthcare, Meta-analysis

Posted Date: February 9th, 2022

DOI: https://doi.org/10.21203/rs.3.rs-1323286/v1

License: (c) (i) This work is licensed under a Creative Commons Attribution 4.0 International License.

Read Full License 


\section{Abstract}

Background: There is strong evidence of headaches following COVID-19 vaccination using any type of vaccine. However, very few studies have examined the headache characteristics and their determinants, especially among healthcare employees who have previously experienced COVID-19 infection. We evaluated and compared the incidence of headache following injection of common types of COVID-19 vaccines to determine factors related to its incidence following vaccination among Iranian healthcare employees who had contracted and recovered from the virus.

Methods: A group of 334 employees who had contracted COVID-19 of different intensities were vaccinated with different types of COVID-19 vaccine at least one month following recovery from the virus. They were assessed for baseline information, type of vaccine received, and relevant headache characteristics.

Results: Overall, $39.2 \%$ of participants reported post-vaccination headache. Of those who reported a previous history of headache, migraine was reported by $51.1 \%$, tension-type by $27.4 \%$, and other types by $21.5 \%$. The mean time between vaccination and the onset of headache was $26.78 \pm 6.93 \mathrm{~h}$, indicating that headache onset was less than $24 \mathrm{~h}$ after vaccination in most participants (83.2\%). The headache reached an estimated peak at $8.62 \pm 2.41 \mathrm{~h}$. Most participants reported a pressure-type headache. The prevalence of post-vaccination headache differed significantly according to the type of vaccine. The highest rates were reported for AstraZeneca, followed by Sputnik V. Multivariate logistic regression analysis showed that the vaccine brand, being female in gender, and the initial COVID-19 severity were the main determinants for predicting post-vaccination headache.

Conclusion: It should be expected that about one-third of healthcare employees will experience headache following COVID-19 vaccination. This is more likely to occur in females and those who have recovered from severe cases of COVID-19.

\section{Introduction}

With the onset of the COVID-19 pandemic in December 2019, efforts began to provide effective and safe medication to treat the disease and prevent its development. As in previous pandemics, industrially advanced societies rapidly began work to produce effective vaccines to combant the disease. Within a few months, the first effective immunogenic vaccines were introduced and gradually approved by international scientific bodies, including the Centers for Disease Control and Prevention (CDC) and the World Health Organization (WHO)[1, 2]. Different brands of vaccine were relatively quickly produced by the United States, China, Germany, Japan, India, and Russia, as well as by Iran and Cuba [3-5] .

As the production and commercialization of these vaccines accelerated, concerns about their possible side effects spread quickly. The advent of variants of the virus, especially the delta strain, caused concern about reduced immune response when vaccines with an immunogenicity of over $90 \%$ saw it decrease to less than $70 \%[6,7]$. More importantly, following the inoculation by various vaccine brands against 
COVID-19, possibly life-threatening side effects were reported. Common COVID-19 vaccine side-effects were local inflammation, headache, muscle pain, nausea, fatigue, fever, and chills[8]. In rare cases, anaphylaxis, thromboembolic events, myocarditis, pericarditis, and even death have been reported, which brings into question the safety of some brands[9].

One of the most common side effects following injection of various vaccines was headache. The ZOE COVID study results reported that the overall prevalence of headache after vaccination by the PfizerBioNTech vaccine was $25-42 \%$ [10]. The CDC reported that approximately one-third of people report experiencing a post-vaccination headache, regardless of the type of vaccine. Fortunately, most of the headaches are mild to moderate though $1 \%$ reporting severe headache after the first inoculation and $3 \%$ after the second inoculation[11]. In Italy, the likelihood of headache increased after vaccination by AstraZeneca, followed by Pfizer[12]. However, information about headache for these, as well as other, brands is limited and requires further evaluation. This is especially important for individuals who have recovered from COVID-19 infection. This study evaluated and compared the incidence of headache following inoculation by different types of commonly used COVID-19 vaccines and determined the factors related to the incidence of headache following vaccination among the Iranian healthcare employees who had recovered after contracting COVID-19.

\section{Materials And Methods}

The commonly used COVID-19 vaccines among healthcare employees included AstraZeneca, Sinopharm (China), Sputnik V (Russia), Bharat Covaxin (India), and COVIran Barekat (Iran). In the current study, 334 health care employees who initially contracted and recovered from COVID-19 of different intensities and who had been vaccinated at least one month after recovery with different brands of vaccine were included. The data was collected between April 2021 and September 2021.

The baseline characteristics of the study participants were collected by online questionnaire. The data included demographics, brand of vaccine, severity of initial COVID-19 attack (quarantined at home or hospitalization in an isolated ward), concomitant clinical symptoms, PCR positivity after vaccination, rate of analgesic use after vaccination, and COVID-19 positivity between inoculations. Information about the post-vaccination headaches included the span of time from vaccination to onset of headache, time span from onset to peak intensity, pattern and location of headache, and medication used for headache relief.

All participants were reassured about the privacy of their information. After explaining the objectives of the project, verbal consent was obtained from all participants. The study objectives were to determine the prevalence of headache and its quality according to the type of vaccine and to determine the effect of vaccination according to gender, initial COVID-19 severity, and previous history of headache. The severity of the COVID-19 was determined based on the Criteria for Clinical Severity of Confirmed COVID-19 released by the $\mathrm{WHO}[1,2]$.

For statistical analysis, results are presented as mean \pm standard deviation (SD) for quantitative variables and are summarized by frequency (percentage) for categorical variables. Continuous variables were 
compared using a t-test or Mann-Whitney test whenever the data did not appear to have a normal distribution or when the assumption of equal variance was violated across the study groups. The multivariable logistic regression model was employed to examine the effect of type of vaccine on postvaccination headache as adjusted for gender, previous history of headache, and COVID-19 severity. A pvalue of $\leq 0.05$ was considered statistically significant. The SPSS version 23.0 for Windows (IBM; USA) was used for statistical analysis.

\section{Results}

A total of 334 hospital employees who had a previous history of COVID-19 infection and who were vaccinated with one of the different types of vaccine available in Iran were assessed. The average age of participants was $36.62 \pm 4.36$ years, of which $72.8 \%$ were female and $27.2 \%$ were male. Of these employees, $12.9 \%$ were vaccinated with AstraZeneca, $16.2 \%$ with Sinopharm, $62.3 \%$ with Sputnik V, $6.9 \%$ with Bharat Covaxin, and $1.8 \%$ with other brands. With regard to the initial COVID-19 severity, $62.6 \%$ quarantined at home, $32.3 \%$ were hospitalized in general wards, and $5.1 \%$ were admitted to ICUs. (Table 1) 
Table 1

Characteristics of study population $(n=334)$

\begin{tabular}{|c|c|c|}
\hline \multicolumn{2}{|l|}{ Characteristics } & \multirow{2}{*}{$\begin{array}{l}\text { Percentage } \\
91(27.2)\end{array}$} \\
\hline Gender & Male & \\
\hline & Female & $243(72.8)$ \\
\hline \multirow[t]{5}{*}{ Type of vaccine } & Astrazeneca & $43(12.9)$ \\
\hline & Sinopharm & $54(16.2)$ \\
\hline & Sputnik & $208(62.3)$ \\
\hline & Bharat Covaxin & $23(6.9)$ \\
\hline & Others & $6(1.8)$ \\
\hline \multirow[t]{3}{*}{ COVID-19 severity } & Hospitalization & $108(32.3)$ \\
\hline & ICU admission & $17(5.1)$ \\
\hline & Quarantine at home & $209(62.6)$ \\
\hline \multirow[t]{7}{*}{ Concomitant symptoms } & Joint pain & $59(17.7)$ \\
\hline & Chills & $13(3.9)$ \\
\hline & Muscular pain & $72(21.6)$ \\
\hline & Runny nose & $23(6.9)$ \\
\hline & Sleep problem & $6(1.8)$ \\
\hline & Dizziness & $8(2.4)$ \\
\hline & Neural symptoms & $20(6.0)$ \\
\hline \multicolumn{2}{|c|}{ PCR positivity after vaccination } & $2(0.6)$ \\
\hline \multicolumn{2}{|c|}{ Analgesic use after vaccination } & $28(8.4)$ \\
\hline
\end{tabular}

Of the total respondents, $39.2 \%$ reported post-vaccination headaches and $30.8 \%$ had a previous history of headache. Of the latter, $51.1 \%$ had experienced migraine, $27.4 \%$ tension-type headache, and $21.5 \%$ other types. The mean time span from vaccination against COVID-19 and the onset of headache was $26.78 \pm$ $6.93 \mathrm{~h}$, indicating that the headache appeared less than $24 \mathrm{~h}$ after vaccination in most participants (83.2\%). The estimated time span from headache onset to its peak was $8.62 \pm 2.41 \mathrm{~h}$. The overall headache duration was $4.22 \pm 1.26 \mathrm{~h}$ and, for $50 \%$ of participants, the headache duration was less than 6 h. 
The most frequent symptom concurrent with the post-vaccination headache was nausea (9.2\%), followed by sensitivity to noise (6.9\%), and photophobia (4.6\%). In most participants, the headache was pressure in form. Most participants reported that the headache was felt diffusely around the head. The severity of the headache was reported by most (93.0\%) to require them to recline with the use of an analgesic (Table 2). 
Table 2

Characteristics of headache after vaccination in study population $(n=334)$

\begin{tabular}{|c|c|c|}
\hline \multicolumn{2}{|l|}{ Characteristics } & Measurement \\
\hline \multicolumn{2}{|l|}{ Prevalence of post-vaccination headache (\%) } & $131(39.2)$ \\
\hline \multirow[t]{3}{*}{ Previous history of headache (\%) } & Migraine & $67(51.1)$ \\
\hline & Tension & $36(27.4)$ \\
\hline & Other types & $28(21.5)$ \\
\hline \multicolumn{2}{|c|}{ Mean time of headache occurrence after vaccination $(\mathrm{h})$} & $26.78 \pm 6.93$ \\
\hline \multirow[t]{4}{*}{ Form of headache after vaccination } & early ( $\leq 24 \mathrm{~h})$ & $109(83.2)$ \\
\hline & 24 to $72 \mathrm{~h}$ & $10(7.6)$ \\
\hline & $72 \mathrm{~h}$ to 7 days & $8(6.1)$ \\
\hline & $>72 \mathrm{~h}$ & $4(3.1)$ \\
\hline \multicolumn{2}{|l|}{ Mean duration of headache (hour) } & $4.22 \pm 1.26$ \\
\hline & Pressure & $97(74.0)$ \\
\hline \multirow[t]{2}{*}{ Pattern of post-vaccination headache (\%) } & Pulsatile & $22(16.8)$ \\
\hline & Neuralgic type & $12(9.2)$ \\
\hline \multirow[t]{7}{*}{ Location of post-vaccination headache (\%) } & Frontal & $14(10.7)$ \\
\hline & Temporal & $13(9.9)$ \\
\hline & Occipital & $4(3.1)$ \\
\hline & Parietal & $7(5.3)$ \\
\hline & Diffuse & $43(32.8)$ \\
\hline & Neck & $1(0.7)$ \\
\hline & Mixed & 49 (37.5) \\
\hline \multirow[t]{3}{*}{ Other symptoms along with headache } & Nausea & $21(9.2)$ \\
\hline & Photophobia & $6(4.6)$ \\
\hline & Sensitivity to sound & $9(6.9)$ \\
\hline \multirow[t]{4}{*}{ Medication used for headache relief (\%) } & Acetaminophen & $65(49.6)$ \\
\hline & Ibuprofen & $17(12.9)$ \\
\hline & Naproxen & $16(12.2)$ \\
\hline & Other analgesics & $24(18.3)$ \\
\hline
\end{tabular}


Figure 1 shows that the prevalence of post-vaccination headaches was significantly different according to the type of vaccine used. In this regard, the headaches were most prevalent following inoculation by AstraZeneca $(62.8 \%)$, followed by Sputnik V $(40.4 \%)$, and Bharat Covaxin $(30.4 \%)(p<0.001)$. Postvaccine headache was found to be significantly higher in females than in males $(43.6 \%$ versus $27.5 \% ; p=$ 0.001). As indicated in Table 3, although the onset of headache (early or delayed) did not differ according to vaccine type; however, the pattern differed. A pressure headache was primarily reported by those vaccinated with AstraZeneca or Sputnik V. A throbbing headache was reported following vaccination with Sinopharm.

Table 3

Quality of headache by type of vaccine used $(n=131)$

\begin{tabular}{|c|c|c|c|c|c|c|}
\hline Characteristics & & $\begin{array}{l}\text { Astrazeneca } \\
\text { (\%) }\end{array}$ & $\begin{array}{l}\text { Sinopharm } \\
(\%)\end{array}$ & $\begin{array}{l}\text { Sputnik } \\
(\%)\end{array}$ & $\begin{array}{l}\text { Bharat } \\
\text { Covaxin } \\
(\%)\end{array}$ & $\begin{array}{l}\mathrm{p}- \\
\text { value }\end{array}$ \\
\hline \multirow[t]{2}{*}{ Form of headache } & early & $23(85.2)$ & 10 (83.3) & $\begin{array}{l}69 \\
(82.1)\end{array}$ & $6(85.7)$ & 0.984 \\
\hline & delayed & $4(14.8)$ & 2 916.7) & $\begin{array}{l}15 \\
(17.9)\end{array}$ & $1(14.3)$ & \\
\hline \multirow[t]{3}{*}{ Headache pattern } & pressure & $20(74.1)$ & $8(66.7)$ & $\begin{array}{l}63 \\
(75.0)\end{array}$ & $4(57.1)$ & 0.046 \\
\hline & pulsatile & $1(3.7)$ & $4(33.3)$ & $\begin{array}{l}13 \\
(15.5)\end{array}$ & $2(28.6)$ & \\
\hline & neuralgic & $6(22.2)$ & $0(0.0)$ & $8(9.5)$ & $1(14.3)$ & \\
\hline \multirow[t]{7}{*}{$\begin{array}{l}\text { Location of } \\
\text { headache }\end{array}$} & frontal & $0(0.0)$ & $2(16.7)$ & $\begin{array}{l}10 \\
(12.0)\end{array}$ & $1(14.3)$ & 0.814 \\
\hline & temporal & $2(7.4)$ & $1(8.3)$ & $\begin{array}{l}10 \\
(12.0)\end{array}$ & $0(0.0)$ & \\
\hline & occipital & $0(0.0)$ & $0(0.0)$ & $4(4.8)$ & $0(0.0)$ & \\
\hline & parietal & $3(11.1)$ & $0(0.0)$ & $4(4.8)$ & $0(0.0)$ & \\
\hline & diffuse & $10(37.0)$ & $5(41.7)$ & $\begin{array}{l}23 \\
(27.7)\end{array}$ & $5(71.4)$ & \\
\hline & neck & $0(0.0)$ & $0(0.0)$ & $1(1.2)$ & $0(0.0)$ & \\
\hline & mixed & $12(44.4)$ & $4(33.3)$ & $\begin{array}{l}31 \\
(37.3)\end{array}$ & $1(14.3)$ & \\
\hline
\end{tabular}


In multivariate logistic regression analysis (Table 4), type of vaccine $(O R=1.328 ; p=0.040)$, female gender $(O R=1.934 ; p=0.017)$, and COVID-19 severity $(O R=3.541 ; p=0.001)$ were the main determinants for predicting post-vaccination headache. A history of headache before vaccination was not found to be associated with the occurrence of post-vaccination headache.

Table 4

Effect of vaccine type on post-vaccination headache by gender, headache history and COVID-19 severity

\begin{tabular}{|lllllll|}
\hline Factor & B & SE & Sig. & $\operatorname{Exp}(\mathrm{B})$ & \multicolumn{2}{l|}{$95.0 \%$ Cl for EXP(B) } \\
\cline { 5 - 7 } & & & & & lower & upper \\
\hline Type of vaccine & 0.283 & 0.138 & 0.040 & 1.328 & 1.013 & 1.740 \\
\hline Male gender & -0.660 & 0.277 & 0.017 & 0.517 & 0.301 & 0.889 \\
\hline History of headache & -0.240 & 0.127 & 0.059 & 0.787 & 0.613 & 1.009 \\
\hline COVID-19 severity & 1.264 & 0.671 & 0.001 & 3.541 & 1.668 & 5.642 \\
\hline Hosmer-Lemeshow goodness of fit: chi-square $=9.428 ; p=0.307$ & \\
\hline
\end{tabular}

\section{Discussion}

The present study is the first to evaluate the occurrence of headache in individuals who have been vaccinated after recovering from an initial infection by COVID-19. In these participants, there were no signs of reinfection following vaccination. However, the predominant finding in the present study was that about one-third of vaccinated individuals showed evidence of different types of headache following vaccination. A review of the literature (Table 5) shows that the post-vaccination headache ranged from $19.5-49.4 \%$ regardless of the type of vaccine or the target population (general population or healthcare employees). 
Table 5

Review of studies on post-vaccination headache

\begin{tabular}{|c|c|c|c|c|c|}
\hline $\begin{array}{l}\text { Author, } \\
\text { Country }\end{array}$ & $\begin{array}{l}\text { Study } \\
\text { type }\end{array}$ & $\begin{array}{l}\text { Population } \\
\text { size }\end{array}$ & $\begin{array}{l}\text { Targeted } \\
\text { population }\end{array}$ & Type of vaccine & $\begin{array}{l}\text { Headache } \\
\text { prevalence }\end{array}$ \\
\hline $\begin{array}{l}\text { Serwaa, } \\
\text { Ghana [13] }\end{array}$ & $\begin{array}{l}\text { cross- } \\
\text { sectional }\end{array}$ & 654 & personnel & AstraZeneca & $27.3 \% 178$ \\
\hline $\begin{array}{l}\text { García- } \\
\text { Azorín, }\end{array}$ & $\begin{array}{l}\text { cross- } \\
\text { sectional }\end{array}$ & 77 & general & $\begin{array}{l}\text { Non-replicant adenovirus } \\
\text { vector-based vaccine }\end{array}$ & $49.4 \% 38$ \\
\hline \multicolumn{6}{|l|}{$\begin{array}{l}\text { Norway } \\
\text { [14] }\end{array}$} \\
\hline $\begin{array}{l}\text { Ekizoglu, } \\
\text { Turkey [15] }\end{array}$ & $\begin{array}{l}\text { cross- } \\
\text { sectional }\end{array}$ & 1819 & personnel & Pfizer & $30.6 \% 556$ \\
\hline $\begin{array}{l}\text { Göbel, } \\
\text { Germany } \\
\text { [16] }\end{array}$ & cohort & 12000 & general & AstraZeneca & $\begin{array}{l}19.5 \% \\
2340\end{array}$ \\
\hline $\begin{array}{l}\text { Sekiguchi, } \\
\text { Japan [17] }\end{array}$ & $\begin{array}{l}\text { cross- } \\
\text { sectional }\end{array}$ & 171 & personnel & Pfizer & $39.7 \% 68$ \\
\hline $\begin{array}{l}\text { Hatmal, } \\
\text { Jordan } \\
\text { [18] }\end{array}$ & $\begin{array}{l}\text { cross- } \\
\text { sectional }\end{array}$ & 2213 & general & $\begin{array}{l}\text { Sinopharm, AstraZeneca, } \\
\text { Pfizer-BioNTech }\end{array}$ & $\begin{array}{l}46.9 \% \\
1038\end{array}$ \\
\hline $\begin{array}{l}\text { Solomon, } \\
\text { Ethiopia } \\
\text { [18] }\end{array}$ & $\begin{array}{l}\text { cross- } \\
\text { sectional }\end{array}$ & 672 & personnel & AstraZeneca & $50.2 \% 337$ \\
\hline $\begin{array}{l}\text { Adam, } \\
\text { Saudi } \\
\text { Arabia [19] }\end{array}$ & $\begin{array}{l}\text { cross- } \\
\text { sectional }\end{array}$ & 330 & general & Pfizer, AstraZeneca & $24.2 \% 86$ \\
\hline $\begin{array}{l}\text { Pokharel, } \\
\text { Nepal, [20] }\end{array}$ & $\begin{array}{l}\text { cross- } \\
\text { sectional }\end{array}$ & 220 & personnel & Covishield & $19.5 \% 43$ \\
\hline $\begin{array}{l}\text { Klugar, } \\
\text { Czech } \\
\text { Republic } \\
{[21]}\end{array}$ & $\begin{array}{l}\text { cross- } \\
\text { sectional }\end{array}$ & 599 & personnel & Pfizer, AstraZeneca & $53.6 \% 321$ \\
\hline $\begin{array}{l}\text { Saeed, } \\
\text { UAE [22] }\end{array}$ & $\begin{array}{l}\text { cross- } \\
\text { sectional }\end{array}$ & 1102 & general & Sinopharm & $10.0 \% 110$ \\
\hline $\begin{array}{l}\text { Almufty, } \\
\text { Iraq [23] }\end{array}$ & $\begin{array}{l}\text { cross- } \\
\text { sectional }\end{array}$ & 1012 & general & Pfizer, AstraZeneca, Sinopharm & $34.0 \% 344$ \\
\hline $\begin{array}{l}\text { Quiroga, } \\
\text { Spain [24] }\end{array}$ & $\begin{array}{l}\text { cross- } \\
\text { sectional }\end{array}$ & 708 & general & Pfizer & $34.0 \% 240$ \\
\hline $\begin{array}{l}\text { Cuschieri, } \\
\text { Malta [25] }\end{array}$ & $\begin{array}{l}\text { cross- } \\
\text { sectional }\end{array}$ & 1480 & personnel & Pfizer & $44.2 \% 655$ \\
\hline
\end{tabular}




\begin{tabular}{|c|c|c|c|c|c|}
\hline $\begin{array}{l}\text { Author, } \\
\text { Country }\end{array}$ & $\begin{array}{l}\text { Study } \\
\text { type }\end{array}$ & $\begin{array}{l}\text { Population } \\
\text { size }\end{array}$ & $\begin{array}{l}\text { Targeted } \\
\text { population }\end{array}$ & Type of vaccine & $\begin{array}{l}\text { Headache } \\
\text { prevalence }\end{array}$ \\
\hline $\begin{array}{l}\text { Kaya, } \\
\text { Turkey [26] }\end{array}$ & cohort & 329 & personnel & Pfizer & $16.8 \%, 56$ \\
\hline $\begin{array}{l}\text { Raid, } \\
\text { Czech } \\
\text { Republic } \\
\text { [27] }\end{array}$ & $\begin{array}{l}\text { cross- }^{-} \\
\text {sectional }\end{array}$ & 92 & personnel & AstraZeneca & $29.3 \%, 27$ \\
\hline $\begin{array}{l}\text { Abu- } \\
\text { Hammad, } \\
\text { Jordan } \\
\text { [28] }\end{array}$ & $\begin{array}{l}\text { cross- }^{-} \\
\text {sectional }\end{array}$ & 409 & personnel & Pfizer, AstraZeneca, Sinopharm & $42.0 \% 172$ \\
\hline $\begin{array}{l}\text { Lee, Korea } \\
\text { [29] }\end{array}$ & $\begin{array}{l}\text { cross- } \\
\text { sectional }\end{array}$ & 265 & personnel & Pfizer & $48.7 \% 129$ \\
\hline $\begin{array}{l}\text { Zhang, } \\
\text { China [30] }\end{array}$ & $\begin{array}{l}\text { cross- } \\
\text { sectional }\end{array}$ & 1526 & personnel & Pfizer & $6.0 \% 92$ \\
\hline $\begin{array}{l}\text { El-Shitany, } \\
\text { Saudi } \\
\text { Arabia [31] }\end{array}$ & $\begin{array}{l}\text { cross- } \\
\text { sectional }\end{array}$ & 124 & general & Pfizer & $22.5 \% 28$ \\
\hline $\begin{array}{l}\text { Kadali, } \\
\text { USA [32] }\end{array}$ & $\begin{array}{l}\text { cross- }^{-} \\
\text {sectional }\end{array}$ & 1245 & personnel & Pfizer & $45.4 \% 565$ \\
\hline $\begin{array}{l}\text { Kim, Korea } \\
\text { [33] }\end{array}$ & $\begin{array}{l}\text { cross- } \\
\text { sectional }\end{array}$ & 1403 & personnel & Pfizer, AstraZeneca & $47.4 \% 665$ \\
\hline $\begin{array}{l}\text { Our study, } \\
\text { Iran }\end{array}$ & $\begin{array}{l}\text { cross- }^{-} \\
\text {sectional }\end{array}$ & 334 & personnel & $\begin{array}{l}\text { AstraZeneca, Sinopharm, } \\
\text { Sputnik V, Bharat Covaxin, } \\
\text { CoVIran Barekat }\end{array}$ & $39.2 \% 131$ \\
\hline
\end{tabular}

Meta-analysis of the relevant studies indicates an overall prevalence of $31.2 \%$ (95\% Cl; $25.3-37.9 \%)$ for headache in all populations and a specific prevalence of $34.6 \%(95 \% \mathrm{Cl} ; 27.4-42.5 \%)$ among healthcare employees. There was considerable heterogeneity across the studies $\left(I^{2}\right.$ values of 99.037 and 98.343 , respectively; $p<0.001$; see Figs. 2 and 3) [13-33]. These divergent results might be due to the type of vaccine used as well as differences among the populations enrolled in the studies. It could be concluded that about one-third of individuals that had been vaccinated against COVID-19 experienced various intensities of headache, with a slightly higher incidence rate among healthcare employees.

Interestingly, in the present study, $83.2 \%$ of participants reported headache within the first $24 \mathrm{~h}$ after vaccination and a mean time between vaccination and headache onset was $26.78 \pm 6.93 \mathrm{~h}$. Göbel et al. [16] reported that the latency between vaccination and the onset of a headache was, on average, $18.0 \pm$ $27.0 \mathrm{~h}$. More than half of the participants experienced a headache in less than $10 \mathrm{~h}$ and $80 \%$ within $24 \mathrm{~h}$ 
after vaccination, which is similar to the findings of the present study. Similarly, Sekiguchi et al. [17] reported that the median onset of headache after the first and second inoculations were 10 and $12 \mathrm{~h}$, respectively, and the mean durations of headache were 4.5 and $8.0 \mathrm{~h}$, respectively. In the present study, the mean duration to onset of headache after vaccination was $4.22 \pm 1.26 \mathrm{~h}$. In $50 \%$ of the participants, the headache duration was less than $6 \mathrm{~h}$ and, in $80 \%$, it was less than $22 \mathrm{~h}$. Göbel et al. [16] reported a mean headache duration of $14.2+21.4 \mathrm{~h}$.

The current study recorded generalized headache in about one-third of participants. Göbel et al.[16] reported that the headache appeared bilaterally in $73.1 \%$ of their subjects and that the most prominent zones were the forehead (38.0\%), followed by the temple region (32.2\%). Sekiguchi et al. [17] reported a rate of bilateral headache in the control group without headache to be $78.8 \%$, for the migraine group to be $62 . \%$, and for the non-migraine headache group to be $75.9 \%$. The participants in the present study primarily experienced pressure type headaches. Göbel et al. [16] reported pressure and dull pain in $49.2 \%$ and $40.7 \%$ of subjects, respectively. Ekizoglu et al. [15] reported throbbing headache in $40.1 \%$ and pressure type headache in $30.4 \%$.

Another important finding was that the occurrence of a post-vaccination headache also was potentially influenced by the factors of female gender and severity of initial COVID-19 illness. Overall, it appears that because migraine and tension headache are more prevalent in females than males [34,35], this could have affected the greater likelihood of post-vaccination headache in females.

In the current study, there was a significant difference in the prevalence of headache by vaccine type among the different communities. As shown, the highest rate of headache was recorded after vaccination with AstraZeneca, followed by Sputnik V. The literature review (Table 5) did not differentiate between vaccines with regard to incidence of headache. For example, the rate of post-vaccination headache following the use of Pfizer ranged broadly from 6.0-48.7\%. However, independent information about the incidence of brands such as Sinopharm and Sputnik V is limited.

There is no documented, comprehensive explanation of the pathomechanisms of headache following vaccination against COVID-19. Some believe that such a headache may originate from the spike protein of the virus used to produce the vaccine[36]. Others propose that the resulting immune response triggered by such proteins plays a significant role[37]. In other words, it could be that flaring pro-inflammatory cascades and secretion of related cytokines and prostaglandins may be responsible for the onset of vaccination-related headache and other concurrent symptoms[38, 39]. It also is possible that the technologies and the materials used for creating vaccines may have a role in the onset of postvaccination headaches. This should be evaluated in future studies.

A limitation of this study was that some of the most commonly used brands globally, such as Pfizer, were not available in Iran, making it impossible to evaluate their post-vaccination headache statistics. Additionally, the pattern of headache among healthcare employees was not evaluated after their exposure to COVID-19. 


\section{Conclusion}

The present study examined healthcare employees who had previously become infected with and recovered from COVID-19 and who then were vaccinated with different types of vaccine. It was found that $39.2 \%$ of such participants experienced headaches soon after vaccination. This post-vaccination event was more common in females than males as well as in those who had experienced more severe initial COVID-19 attacks.

Among all brands used in the study population, the highest rate of post-vaccination headache was for the AstraZeneca and Sputnik V types. Considering that the people of this world will continue to have to cope with COVID-19 and obtain vaccinations against it, it is advisable to identify and classify post-vaccination headaches to aid in its appropriate management. Also, differentiation of such headaches from those with other origins, such as cerebrovascular thrombotic events, can be vital to their successful treatment.

\section{Declarations}

- Ethics approval and consent to participate: Tehran University of Medical Sciences ethical committee approved the study with the ethic code of: IR.TUMS.NI.REC.1400.054

- Consent for publication: All participants signed the informed consent.

- Availability of data and materials: The datasets used and/or analysed during the current study are available from the corresponding author on reasonable request.

- Competing interests: The authors declare that they have no competing interests.

- Funding: This study was done with no fund.

- Authors' contributions: SN, designed the research idea, participated in data gathering, manuscript writing and editing. MT, data gathering and editing the manuscript. EJ, data gathering and editing the manuscript. MS, analyzing the data and doing meta-analysis and writing the manuscript. DS, data gathering

- Acknowledgements: We thank all the participants in the present study and our colleagues who helped us in data gathering. Also, the authors would like to thank the Epidemiology and Biostatistics team at the Research Development Center of Sina University Hospital for their technical assistance.

\section{References}

1. Ghasemiyeh, P., et al., A focused review on technologies, mechanisms, safety, and efficacy of available COVID-19 vaccines. International immunopharmacology, 2021. 100: p. 108162.

2. Khan, A., et al., SARS-CoV-2 new variants: Characteristic features and impact on the efficacy of different vaccines. Biomedicine \& Pharmacotherapy, 2021. 143: p. 112176.

3. Scott, J., A. Richterman, and M. Cevik, Covid-19 vaccination: evidence of waning immunity is overstated. 2021, British Medical Journal Publishing Group. 
4. Gómez-Carballa, A., et al., Superspreading in the emergence of COVID-19 variants. Trends in Genetics, 2021. 37(12): p. 1069-1080.

5. Mehraeen, E., et al., Vaccines for COVID-19: A Review of Feasibility and Effectiveness. Infectious disorders drug targets, 2021.

6. Raman, R., K.J. Patel, and K. Ranjan, COVID-19: Unmasking Emerging SARS-CoV-2 Variants, Vaccines and Therapeutic Strategies. 2021.

7. Tavilani, A., et al., COVID-19 vaccines: Current evidence and considerations. Metabolism open, 2021. 12: p. 100124.

8. Pascual-Iglesias, A., et al., An overview of vaccines against SARS-CoV-2 in the COVID-19 pandemic era. Pathogens, 2021. 10(8): p. 1030.

9. Cai, C., et al., A comprehensive analysis of the efficacy and safety of COVID-19 vaccines. Molecular Therapy, 2021. 29(9): p. 2794-2805.

10. Burki, T.K., Lifting of COVID-19 restrictions in the UK and the Delta variant. The Lancet Respiratory Medicine, 2021. 9(8): p. e85.

11. Anand, P. and V.P. Stahel, Review the safety of Covid-19 mRNA vaccines: a review. Patient safety in surgery, 2021. 15(1): p. 1-9.

12. Mattiuzzi, C. and G. Lippi, Headache after COVID-19 vaccination: updated report from the Italian Medicines Agency database. Neurological Sciences, 2021: p. 1-2.

13. Serwaa, D., et al., Non-life-threatening adverse reactions from COVID-19 vaccine; a cross-sectional study with self-reported symptoms among Ghanaian healthcare workers. Human Vaccines \& Immunotherapeutics, 2021: p. 1-6.

14. García-Azorín, D., et al., Delayed headache after COVID-19 vaccination: a red flag for vaccine induced cerebral venous thrombosis. The journal of headache and pain, 2021. 22(1): p. 1-5.

15. Ekizoglu, E., et al., The characteristics of COVID-19 vaccine-related headache: Clues gathered from the healthcare personnel in the pandemic. Cephalalgia, 2021: p. 03331024211042390.

16. Göbel, C.H., et al., Clinical characteristics of headache after vaccination against COVID-19 (coronavirus SARS-CoV-2) with the BNT162b2 mRNA vaccine: a multicentre observational cohort study. Brain Communications, 2021. 3(3): p. fcab169.

17. Sekiguchi, K., et al., Incidence of headache after COVID-19 vaccination in patients with history of headache: A cross-sectional study. Cephalalgia, 2021: p. 03331024211038654.

18. Solomon, Y., et al., COVID-19 Vaccine: Side Effects After the First Dose of the Oxford AstraZeneca Vaccine Among Health Professionals in Low-Income Country: Ethiopia. Journal of Multidisciplinary Healthcare, 2021. 14: p. 2577.

19. Adam, M., et al., Evaluation of Post-Vaccination Symptoms of Two Common COVID-19 Vaccines Used in Abha, Aseer Region, Kingdom of Saudi Arabia. Patient preference and adherence, 2021. 15: p. 1963. 
20. Pokharel, K., B.R. Dawadi, and A. Karki, Side Effects after Second Dose of Covishield Vaccine among Healthcare Workers: A Descriptive Cross-sectional Study. JNMA: Journal of the Nepal Medical Association, 2021. 59(238): p. 577.

21. Klugar, M., et al., Side effects of mRNA-based and viral vector-based COVID-19 vaccines among German healthcare workers. Biology, 2021. 10(8): p. 752.

22. Saeed, B.Q., et al., Side effects and perceptions following Sinopharm COVID-19 vaccination. International Journal of Infectious Diseases, 2021. 111: p. 219-226.

23. Almufty, H.B., et al., Potential adverse effects of COVID19 vaccines among Iraqi population; a comparison between the three available vaccines in Iraq; a retrospective cross-sectional study. Diabetes \& Metabolic Syndrome: Clinical Research \& Reviews, 2021. 15(5): p. 102207.

24. Quiroga, B., et al., COVID-19 Vaccination among Spanish nephrologists: Results of survey on acceptance and side effects. Journal of Healthcare Quality Research, 2021.

25. Cuschieri, S., et al., Adverse reactions to Pfizer-BioNTech vaccination of healthcare workers at Malta's state hospital. International Journal of Clinical Practice, 2021. 75(10): p. e14605.

26. Kaya, F. and E. Pirincci, Determining the frequency of serious adverse reactions of inactive SARSCOV-2 vaccine. Work, 2021(Preprint): p. 1-5.

27. Riad, A., et al., Safety of ChAdOx1 nCoV-19 Vaccine: Independent Evidence from Two EU States. Vaccines, 2021. 9(6): p. 673.

28. Abu-Hammad, O., et al., Side Effects Reported by Jordanian Healthcare Workers Who Received COVID-19 Vaccines. Vaccines, 2021. 9(6): p. 577.

29. Lee, Y.W., et al., Adverse Reactions of the Second Dose of the BNT162b2 mRNA COVID-19 Vaccine in Healthcare Workers in Korea. Journal of Korean medical science, 2021. 36(21).

30. Zhang, M.-X., et al., Safety of an inactivated SARS-CoV-2 vaccine among healthcare workers in China. Expert Review of Vaccines, 2021: p. 1-8.

31. El-Shitany, N.A., et al., Minor to moderate side effects of Pfizer-BioNTech COVID-19 vaccine among Saudi residents: A retrospective cross-sectional study. International journal of general medicine, 2021. 14: p. 1389.

32. Kadali, R.A., et al., Side effects of BNT162b2 mRNA COVID-19 vaccine: A randomized, cross-sectional study with detailed self-reported symptoms from healthcare workers. International Journal of Infectious Diseases, 2021. 106: p. 376-381.

33. Kim, S.-H., et al., Adverse events in healthcare workers after the first dose of ChAdOx1 nCoV-19 or BNT162b2 mRNA COVID-19 vaccination: a single center experience. Journal of Korean medical science, 2021. 36(14).

34. Hassan, M., et al., Neurological complications of SARS-CoV-2: A single-center case series authors. Brain Hemorrhages, 2021. 2(4): p. 161-164.

35. Mouliou, D.S., O.S. Kotsiou, and K.I. Gourgoulianis, Estimates of COVID-19 Risk Factors among Social Strata and Predictors for a Vulnerability to the Infection. International Journal of Environmental 
Research and Public Health, 2021. 18(16): p. 8701.

36. Alnefaie, A. and S. Albogami, Current approaches used in treating COVID-19 from a molecular mechanisms and immune response perspective. Saudi Pharmaceutical Journal, 2020.

37. Schlickeiser, S., et al., Disease severity, fever, age, and sex correlate with SARS-CoV-2 neutralizing antibody responses. Frontiers in immunology, 2021: p. 3888.

38. Steiner, S., et al., HCoV-and SARS-CoV-2 cross-reactive T cells in CVID patients. Frontiers in immunology, 2020. 11.

39. Orsucci, D., et al., Neurological features of COVID-19 and their treatment: a review. Drugs in context, 2020. 9.

\section{Figures}

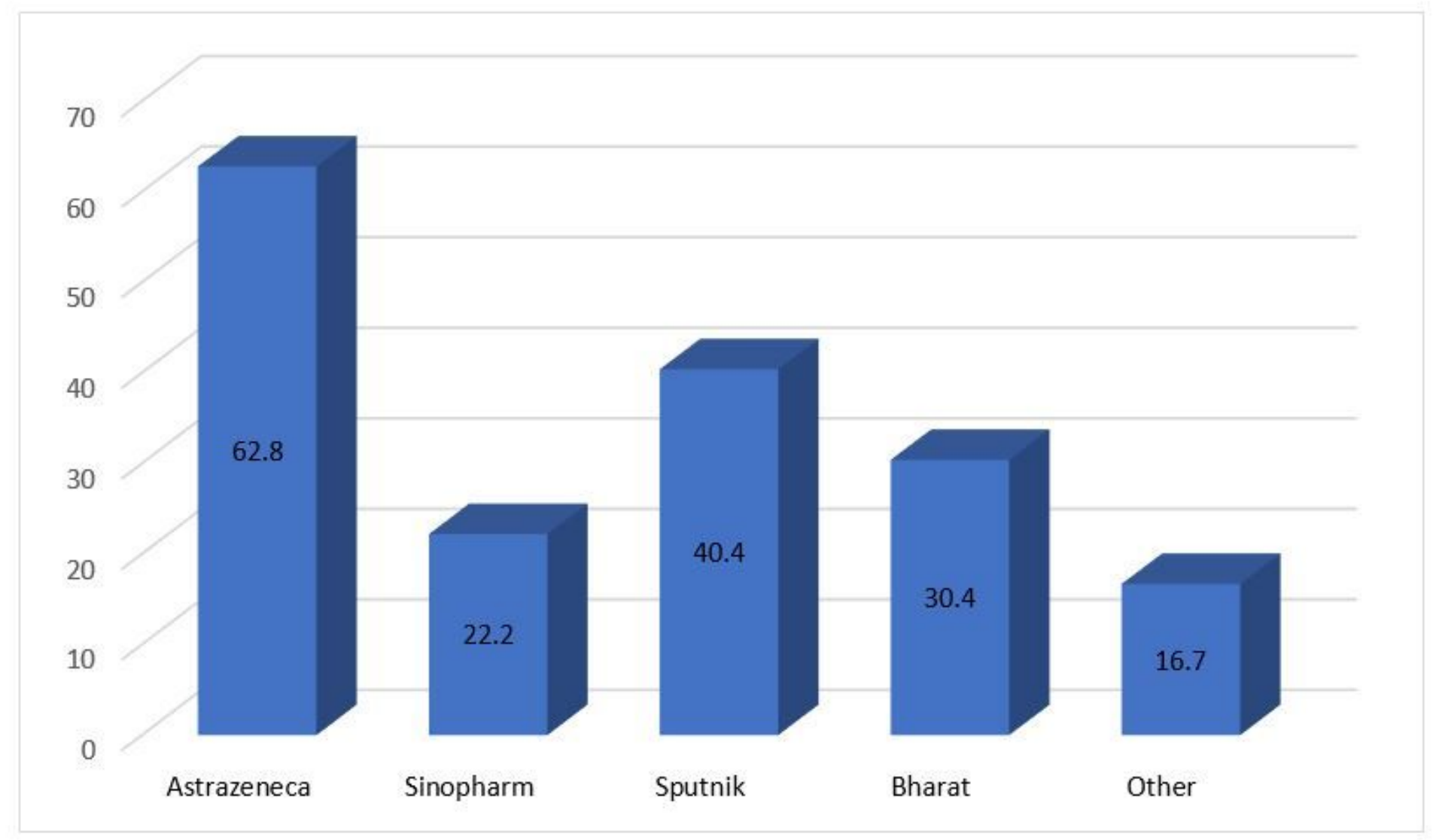

\section{Figure 1}

Prevalence of post-vaccine headache by type of vaccine used $(p=0.001)$ 


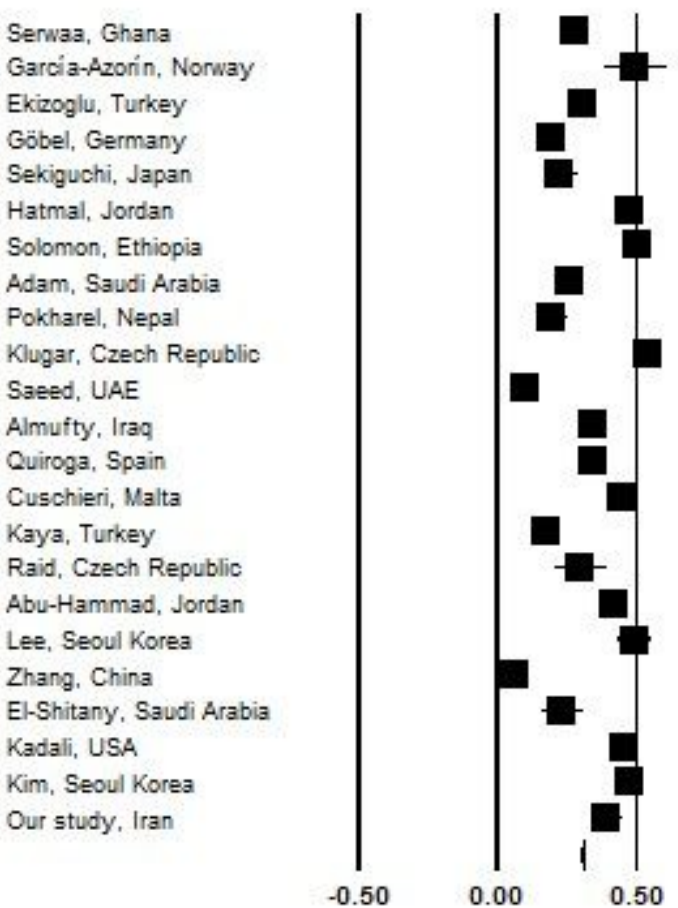

Figure 2

Prevalence of post-vaccine headache among total population in different studies

\section{Study name}

\section{Event rate and $95 \% \mathrm{Cl}$}

Ekizoglu, Turkey Sekiguchi, Japan

Solomon, Ethiopia

Pokharel, Nepal

Klugar, Czech Republic Cuschieri, Malta

Kaya, Turkey

Raid, Czech Republic

Abu-Hammad, Jordan

Lee, Seoul Korea

Zhang, China

Kadali, USA

Kim, Seoul Korea

Our study, Iran

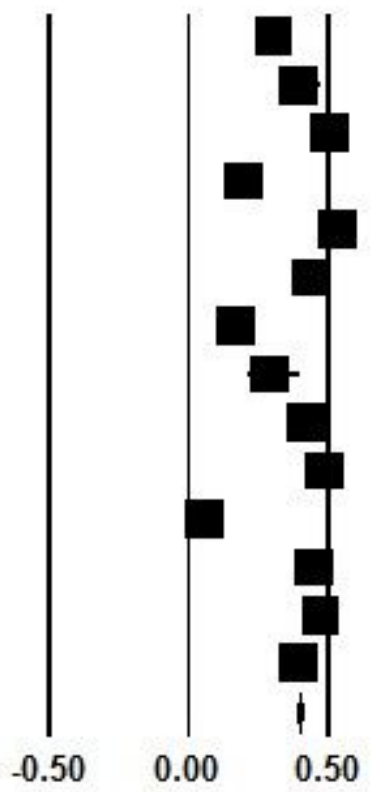

Figure 3 
Prevalence of post-vaccine headache among healthcare employees in different studies 